\title{
AKIBAT HUKUM PEMBUBARAN KOPERASI TERHADAP HAK DAN KEWAJIBAN ANGGOTA
}

\author{
Riandy Arya Satria, I Nyoman Putu Budiartha, Ni Gusti Ketut Sri Astiti \\ Fakultas Hukum, Universitas Warmadewa, Denpasar-Bali, Indonesia \\ komangriandi@gmail.com, budiarthaputu59@gmail.com, notarisppatsriastiti@yahoo.com
}

\begin{abstract}
Abstrak
Dalam menjalankan usaha koperasi tentunya pasang surut situasi ekonomi sangat mempengaruhi untung ruginya suatu usaha, di dalam kondisi pasang koperasi bisa berkembang dan mengembangkan usahanya sehingga semakin besar, tetapi dalam kondisi surut koperasi juga bisa mengalami kerugian yang akan berdampak bagi kelangsungan usaha sampai menyebabkan koperasi bangkrut atau pembubaran koperasi. Pembubaran koperasi tentu mempunyai akibat hukum baik bagi pengurus maupun anggota. Tujuan dari penelitian ini adalah mengetahui akibat hukum pembubaran koperasi terhadap hak dan kewajiban anggota. Penelitian ini menggunakan penelitian normatif dengan pendekatan peraturan perundang-undangan, pendekatan konseptual, dan pendekatan kasus. Sumber bahan hukum yang digunakan berupa sumber hukum sekunder, primer dan tersier kemudian dianalisis secara deskriptif. Hasil penelitian mengungkapkan bahwa akibat hukum yang terjadi setelah dilakukannya pembubaran koperasi, yaitu badan hukum koperasi wajib dilakukan penyelesaian, transaksi operasional dihentikan, karyawan dapat diputuskan hubungan kerja, para anggota tidak dapat lagi mengundurkan diri, kekuasaan perangkat koperasi dibekukan juga digantikan oleh likuidator, dan pengurus maupun pengawas dapat diminta pertanggungjawabannya baik secara perdata maupun pidana jika terbukti karena kesalahan dan kelalaiannya koperasi mengalami kebangkrutan, Selain itu badan hukum dari koperasi tersebut juga akan dihapus.
\end{abstract}

Kata Kunci: Koperasi, Pailit, Pembubaran Koperasi

\begin{abstract}
In running a cooperative business, of course, the ups and downs of the economic situation greatly affect the profit and loss of a business, in the ups and downs the cooperative can develop and develop its business so that it gets bigger, but in the ebb and flow conditions the cooperative can also experience losses that will have an impact on business continuity to cause the cooperative to go bankrupt or dissolution of the cooperative. The dissolution of a cooperative certainly has legal consequences for both the management and the members. The purpose of this study was to determine the legal consequences of the dissolution of the cooperative on the rights and obligations of members. This study uses normative research with a statutory approach, a conceptual approach, and a case approach. Sources of legal materials used in the form of secondary, primary and tertiary legal sources and then analyzed descriptively. The results of the study reveal that the legal consequences that occur after the dissolution of the cooperative, namely the cooperative legal entity must be settled, operational transactions are terminated, employees can be terminated, members can no longer resign, the powers of the cooperative apparatus are frozen and are also replaced by liquidators, and management and supervisors can be held accountable both civilly and criminally if it is proven that due to their mistakes and negligence the cooperative has gone bankrupt. In addition, the legal entity of the cooperative will also be deleted.
\end{abstract}

Keywords: Cooperative, Bankruptcy, Cooperative Dissolution

\section{PENDAHULUAN}

Demi mewujudkan mimpi menjadi sebuah negara yang maju ada banyak faktor yang menentukan tingkat keberhasilan suatu negara bisa dikatakan sebagai negara maju. Selain pendidikan, kesehatan, perekonomian yang baik menjadi salah satu faktor kunci untuk meningkatkan taraf kehidupan masyarakat. Salah satu upaya yang bisa dilakukan untuk meningkatkan perekonomian di masyarakat yakni membentuk badan usaha berbadan hukum yaitu koperasi. Koperasi merupakan usaha bersama yang memiliki izin badan hukum, pada dasarnya pembentukan koperasi dilandasi oleh semangat gotong royong untuk membantu para anggota nya dalam memenuhi kebutuhan hidupnya sehari hari.

Dasar hukum dari keberadaan koperasi di Indonesia adalah Pasal 33 Undang Undang Negara Republik Indonesia Tahun 1945 dan Undang Undang No. 25 Tahun 1992 tentang perkoperasian. 
Pada tahun 2012 sempat dibuat Undang Undang No. 17 Tahun 2012 tentang perkoperasian tetapi karna Undang Undang ini dirasa tidak sesuai dengan jati diri koperasi maka UU No. 17 Tahun 2012 digugat ke Mahkamah Konstitusi dan dibatalkan seluruh materi muatan Undang Undang oleh ketua majelis hakim Mahkamah Konstitusi, dan untuk menghindari kekosongan hukum maka Mahkamah menyatakan berlaku kembali ke Undang-undang No. 25 Tahun 1992 tentang perkoperasian.

Namun dalam kenyataannya tidak semua usaha koperasi bisa berjalan dengan mulus dan lancar, banyak koperasi yang harus menghadapi berbagai hambatan dan rintangan dalam menjalankan usahanya seperti kekurangan modal usaha, kurangnya potensi pemahaman sumber daya manusia koperasi, rendahnya pemahaman anggota dan pengurus terhadap koperasi, pinjaman kredit yang tidak lancar dan masih banyak lagi hambatan yang membuat koperasi tidak bisa bertahan atau pailit (Atmadja \& Budiartha, 2018).

Kepailitan terhadap koperasi pada dasarnya mengacu pada Undang-undang Perkoperasian, Peraturan Pemerintah No. 14 Tahun 1994 dan juga Undang Undang Kepailitan. Namun demikian apabila koperasi dibubarkan maka akan sangat berdampak kepada anggota yang dalam hal ini merupakan sebagai pemilik dari koperasi tersebut yang seringkali terabaikan hak hak nya jika terjadi kasus pembubaran koperasi.

Berdasarkan penelitian terdahulu, menurut (N.A et al., 2016) keputusan pembubaran koperasi dapat berdasarkan keputusan rapat anggota dan keputusan pemerintah. Tanggungjawab pengurus koperasi terhadap pembubaran koperasi dilihat dari Pasal 34 Undang-undang Perkoperasian baik bersama maupun pribadi menanggung kerugian yang diderita oleh koperasi itu sendiri apabila pengurus tersebut terbukti melakukan kesengajaan atau kelalaian. Adapun pelaksanaan pembubaran Koperasi dapat dilakukan melalui dua cara, yaitu melalui Keputusan Rapat Anggota dan Keputusan Pemerintah (Mahsar, 2020). Lebih lanjut (Gultom et al., 2015) Pembubaran Koperasi dapat dilakukan berdasarkan Keputusan rapat anggota dan Keputusan Pemerintah. Hal tersebut diperkuat dengan Pasal 47 Undang-Undang Nomor 25 Tahun 1992 tentang Perkoperasian.

Maka berdasarkan uraian diatas, penelitian ini bertujuan untuk mengungkap akibat hukum pembubaran koperasi terhadap hak dan kewajiban anggota.

\section{METODE PENELITIAN}

Penelitian ini menggunakan penelitian normatif, yaitu penelitian yang mengkaji ketentuan hukum positif tertulis secara sistematis terkait terhadap Koperasi. Penelitian hukum ini dilakukan untuk mencari solusi dari permasalahan atas kasus hukum yang terjadi. Hasil yang ingin diperoleh adalah memberikan jawaban apa yang harus dilakukan jika menghadapi masalah yang sama seperti yang dibahas penulis. Di dalam melakukan penelitian hukum skripsi ini terdapat beberapa pendekatan. Pendekatan yang digunakan adalah pendekatan peraturan perundang-undangan (statute approach), pendekatan konseptual (conceptual approach), dan pendekatan kasus (case approach) (Soemitro, 1998). Sumber bahan hukum yang digunakan berupa sumber hukum sekunder, primer dan tersier yang didapat dari menganalisis buku-buku, jurnal-jurnal dan penelitian terdahulu yang memiliki keterkaitan dengan judul penulisan ini serta bahan hukum tersier yang dapat menunjang bahan hukum primer dan sekunder seperti kamus-kamus hukum dan tulisan yang dapat diakses melalui internet. Bahan-bahan hukum yang diperoleh kemudian dianalisis dengan menggunakan teknik deskriptif kualitatif.

\section{HASIL DAN PEMBAHASAN}

\section{Akibat Hukum Pembubaran Koperasi Terhadap Hak dan Kewajiban Anggota}

Koperasi mulai dikenal pada permulaan abad 19 sebagai reaksi terhadap sistem liberalisme ekonomi yang terjadi pada waktu itu kumpulan orang orang yang mempunyai modal besar menguasai kehidupan bermasyarakat. Koperasi berasal dari kata Co dan Operation yang berarti bekerja gotong royong untuk mencapai tujuan bersama (Hendrawin, 2014). Dasar hukum koperasi di indonesia adalah Pasal 33 Undang Undang Negara Republik Indonesia Tahun 1945 dan Undang Undang No 25 Tahun 1992 tentang perkoperasian. Sejarah perjalanan koperasi di Indonesia dapat ditarik benang merah yang menerangkan koperasi di Indonesia lahir dan tumbuh dari proses menyimpan dan meminjam, artinya Koperasi simpan pinjam merupakan batu pijakan berkembangnya perkoperasian di indonesia (Tamba, 2008). Ada dua jenis koperasi berdasarkan cara pendiriannya yang diatur dalam Permen Koperasi dan UKM Nomor 9 Tahun 2018 yakni sebagai berikut: Koperasi primer dibangun berdasarkan anggota orang perseorangan dengan minimal jumlah anggota 
20 orang dan Koperasi sekunder dibangun berdasarkan anggota badan hukum koperasi dengan minimal jumlah anggota 3 koperasi.

Proses pendirian sebuah koperasi dimulai dengan menyelenggarakan rapat awal pendirian yang diikuti oleh para pendiri koperasi, notaris, yang mana bersamaan dengan rapat pendirian tersebut dapat dilakukan pemberian informasi awal tentang perkoperasian oleh pejabat penyuluh dinas koperasi dan ukm setempat. Dimana kehadiran pejabat tersebut bertujuan antara lain untuk memberi arahan berkenaan dengan pembentukan koperasi, melihat proses pelaksanaan rapat pembentukan, sebagai narasumber apabila ada pertanyaan berkaitan dengan perkoperasian dan untuk meneliti isi konsep anggaran dasar yang dibuat oleh para pendiri. Rapat tersebut wajib diikuti paling sedikit oleh 20 orang untuk pendirian koperasi primer dan 3 badan hukum koperasi yang diwakili oleh pengurus dan/atau anggota yang diberi kuasa untuk pendirian koperasi sekunder. Dalam rapat pendirian tersebut membahas tentang pokok-pokok materi rancangan anggaran dasar, rencana kerja, dan juga calon pengurus dan pengawas koperasi yang akan dibentuk. Hasil rapat kemudian dibuat ke dalam notulen rapat atau berita acara rapat untuk dimasukkan ke dalam rancangan anggaran dasar koperasi.

Selanjutnya, nama koperasi yang telah disepakati oleh para pendiri harus diverivikasi oleh notaris pada sistem administrasi layanan badan hukum koperasi (Sisminbhkop). Format permohonan nama koperasi paling sedikit memuat nama koperasi yang dipesan dan jenis koperasi. Koperasi yang telah memperoleh persetujuan nama wajib mengajukan permohonan Akta Pendirian dalam waktu paling lama 30 hari. Untuk mendapatkan pengesahan akta pendirian Koperasi, pendiri atau kuasa para pendiri mengajukan permohonan pengesahan secara tertulis kepada menteri melalui Sisminbhkop. Pengisian format pengesahan akta pendirian koperasi juga harus dilengkapi dengan dokumen pendukung yang diserahkan secara elektronik. Setelah permohonan disetujui Menteri Hukum dan HAM akan menerbitkan keputusan menteri secara elektronik mengenai pengesahan akta pendirian koperasi. Sehabis pendirian koperasi disahkan melalui keputusan menteri, dalam menyelenggarakan usahanya koperasi harus mengajukan permohonan perizinan berusaha lainnya sesuai dengan ketentuan perundang-undangan yang berlaku.

Dasar hukum dari pembubaran koperasi adalah Undang Undang No. 25 Tahun 1992 Tentang Perkoperasian dan juga Peraturan Pemerintah Nomor 17 Tahun 1994 Tentang pembubaran koperasi oleh pemerintah. Sebelum membahas mekanisme pembubaran ada baiknya kita mengetahui faktor apa saja yang menyebabkan pembubaran koperasi. Diantaranya kredit macet, management sumber daya manusia yang belum optimal, perijinan dan akses permodalan. Kata kredit berasal dari bahasa Yunani yaitu credere yang berarti kepercayaan. Kredit macet atau non performing loan merupakan risiko yang terdapat dalam setiap pemberian kredit oleh koperasi kepada anggotanya, risiko tersebut berupa keadaan di mana anggota tidak dapat membayar angsuran kredit tepat pada waktunya (Rijanto, 2014). meskipun demikian tidak semua kredit yang bermasalah adalah kredit macet. Penggolongan kredit sesuai aturan dari ojk meliputi lancar, kurang lancar, diragukan dan macet. Ada 2 faktor yang menyebabkan terjadinya kredit macet yakni faktor internal dan eksternal debitur, jika dari faktor internal ada kesengajaan dari debitur untuk melakukan wanprestasi, atau debitur sedang mengalami keadaan dimana tidak bisa membayar bukan karena sengaja tetapi karena debitur sedang sakit sehingga tidak bisa mencari penghasilan karena itu debitur tidak bisa membayar. Jika dilihat dari faktor eksternal kondisi ekonomi dan politik sangat mempengaruhi yang berimbas pada perekonomian masyarakat, bisa jadi debitur tidak bisa membayar karena perusahaan tempatnya bekerja ditutup akibat pandemic covid-19 atau terkena dampak bencana alam yang berakibat cukup fatal sehingga tempat usahanya tidak bisa beroperasional lagi. Selain kredit macet atau bermasalah, sumber daya manusia yang kurang bagus merupakan salah satu elemen yang dapat menentukan koperasi bisa mengalami kepailitan. Untuk mengurangi resiko kerugian yang akan ditanggung, dibutuhkan trik atau langkah langkah untuk mengelola sumber daya manusia dalam koperasi tersebut.

Manajemen sumber daya manusia adalah deretan proses yang dimulai dari kegiatan perencanaan, pelaksanaan, analisis dan evaluasi pekerjaan (Riani, 2013). Adapun manfaat ataupun fungsi dari manajemen sumber daya manusia yang dilakukan untuk menentukan produktivitas dan profit dalam perusahaan, yaitu meliputi :

1. Staffing atau Pengaturan Keanggotaan 
Setiap individu memiliki keunikan dan keunggulan masing-masing. Disinilah peran manajemen SDM yaitu menempatkan individu pada tempat yang cocok dan sesuai dengan kemampuannya.

2. Evaluasi

Evaluasi dalam manajemen sumber daya manusia dilakukan agar kesalahan yang ada bisa diperbaiki. Sedangkan jika ada keunggulan maka diberikan reward atau apresiasi kerja dengan terus mendorong untuk menjadi pribadi yang lebih baik.

3. Reward

Pemberian reward dalam rangka apresiasi kerja yang dilakukan oleh setiap individu. Semakin baik kinerja orang maka reward yang diberikan lebih baik daripada yang lainnya.

4. Pemberhentian

Terkadang langkah ini harus dilakukan untuk sebuah keputusan efisiensi dan efektifitas perusahaan terhadap sumber daya manusia yang memiliki mutu kurang baik.

Setelah mengetahui faktor faktor penyebab pailit atau bangkrutnya koperasi maka dirasa perlu untuk mengetahui mekanisme pembubaran sebuah koperasi. Pembubaran koperasi berdasarkan kehendak Rapat anggota ini boleh memutuskan untuk membubarkan koperasi (Shubhan, 2009). Dikarenakan rapat anggota merupakan perangkat organisasi yang memegang kekuasaan tertinggi dalam Koperasi. sebelum memutuskan untuk membubarkan Koperasi penting kiranya semua pihak memperhatikan segala aspek dan semua kemungkinan dari keputusan yang akan diambil tersebut. Jika ternyata Koperasi dinilai tidak dapat melanjutkan kegiatan usahanya barulah rapat anggota boleh mengambil keputusan untuk membubarkan koperasi tersebut. Apabila rapat anggota telah sepakat memutuskan untuk membubarkan Koperasi, maka pengurus atau mereka yang diberi kuasa oleh rapat anggota wajib menginformasikan secara tertulis keputusan pembubaran Koperasi tersebut kepada semua kreditor koperasi, pihak yang berkepentingan dan juga pemerintah. Selain itu berdasarkan Pasal 46 Undang Undang No 25 Tahun 1992, Pemerintah diberikan kewenangan untuk membubarkan Koperasi berdasarkan alasan-alasan tertentu, Misalnya ternyata koperasi telah terbukti melakukan perbuatan yang melanggar hukum, atau karena koperasi terbukti sudah melenceng dengan kepentingan para anggotanya, tidak patuh dengan Undang-undang Perkoperasian atau Anggaran dasar Koperasi, maka Koperasi yang seperti itu lebih baik dibubarkan demi kebaikan bersama.

Proses pembubaran koperasi oleh pemerintah dimulai dengan adanya laporan atau dugaan pelanggaran koperasi lalu dinas koperasi melakukan investigasi untuk menemukan bukti bukti pendukung, setelah ditemukan bukti yang cukup dinas koperasi mengirimkan surat pembubaran koperasi, dalam waktu paling lambat 2 bulan koperasi berhak mengajukan keberatan atau tidak. Proses selanjutnya adalah pembentukan tim penyelesai yang bertugas untuk menyelesaikan proses pengembalian hak anggota dan nasabah. Setelah semua hak anggota selesai barulah badan hukum koperasi bisa dicabut.

Dalam pemahaman hukum, secara harifah yang dimaksud dengan Hak adalah semua hal yang pantas dan mutlak untuk diterima oleh manusia sebagai masyarakat di suatu negara sejak masih berada dalam kandungan yang dilindungi secara hukum. Hak kebendaan berhubungan dengan kepemilikan langsung atas suatu objek yang dapat dilindungi terhadap setiap orang, seperti hak milik. Sedangkan hak perorangan memberikan suatu tuntutan atau penagihan terhadap seseorang seperti hak menagih pembayaran. Dalam hukum romawi, keduanya disebut dengan actions In rem untuk tuntutan kebendaan dan actiones in personam untuk tuntutan perseorangan. Hak kemerdekaan adalah hak yang memberi kebebasan pada seseorang dalam menjalankan aktivitas yang dilindungi oleh hukum, tetapi dengan catatan tidak mengganggu, melanggar dan menyalahgunakan haknya sehingga dapat melanggar hak orang lain.

Kewajiban adalah segala sesuatu yang dianggap sebagai keharusan dalam melaksanakan tugas oleh individu sebagai masyarakat dari suatu negara untuk mendapatkan hak yang pantas untuk diperoleh. Kewajiban pada umumnya mengarah pada suatu kedisiplinan bagi individu dalam melaksanakan peran sebagai anggota warga negara demi memperoleh pengakuan akan hak yang sesuai dengan pelaksanaan kewajiban tersebut. Kewajiban publik di dalam bermasyarakat berkorelasi dengan hak publik yaitu wajib mematuhi hak publik dan juga kewajiban perdata orang lain, yang muncul dari perjanjian yang berkorelasi dengan hak perdata. 
Di Dalam berkegiatan usaha koperasi, Undang-undang memberikan sejumlah hak dan membebankan sejumlah kewajiban serta larangan kepada kedua pihak baik koperasi maupun anggota koperasi. Pengaturan tentang hak, kewajiban, dan larangan itu bertujuan untuk menciptakan hubungan bisnis yang sehat antara koperasi dan anggotanya, sekaligus menciptakan iklim berusaha koperasi yang kondusif bagi perkembangan usaha perekonomian nasional pada umumnya (Udaya et al., 2013). Hak dan kewajiban para pihak tidak boleh saling merugikan. Hak dan kewajiban bisa terlihat dalam tindakan perorangan atau kelompok. Salah satu aksi tersebut adalah tindakan antara koperasi dengan anggotanya dalam menjalankan transaksi keuangan. Demi kelancaran transaksi tersebut perlu diterapkan ketentuan-ketentuan yang berlaku agar semua dapat berjalan dengan tertib, lancar, dan teratur serta mempunyai kepastian hukum bagi para pihak. Terdapat pokok-pokok hak dari koperasi yakni: Hak menerima pembayaran, Hak mendapat perlindungan hukum, Hak membela diri, Rehabilitasi.

Sebagai konsekuensi dari hak koperasi yang telah disebutkan pada uraian sebelumnya, maka kepada koperasi juga dibebankan pula kewajiban yakni:

1. Beritikad baik dalam menjalankan usahanya dan menggerakan roda perekonomian masyarakat.

2. Memberi informasi yang benar, jelas, dan jujur mengenai produk yang ditawarkan kepada anggota.

3. Menjamin mutu produk koperasi baik simpanan maupun pinjaman sudah sesuai aturan yang berlaku.

Hak dan kewajiban anggota koperasi diatur dalam pasal 20 UU No. 25 Tahun 1992. Hak dari anggota koperasi adalah sebagai berikut:

1. Menghadiri, menyatakan pendapat dan memberikan suara dalam rapat anggota.

2. Memilih dan atau dipilih menjadi pengurus.

3. Meminta diadakan rapat anggota menurut ketentuan-ketentuan dalam anggaran dasar. Kewajiban anggota koperasi adalah sebagai berikut:

a) Mematuhi anggaran dasar dan anggaran rumah tangga koperasi serta semua keputusan yang telah disepakati bersama dalam rapat anggota.

b) Berpartisipasi dalam kegiatan usaha yang diselenggarakan oleh koperasi.

c) Mengembangkan dan memelihara kebersamaan azas kekeluargaan.

Tidak satupun orang yang dapat mencabut hak anggota koperasi, termasuk Pengurus sekalipun. Hak dan kewajiban seorang anggota koperasi akan gugur hanya saat dia tidak lagi menjadi anggota. Pembubaran koperasi sebagai badan hukum tentu mempunyai akibat hukum baik menyangkut hak dan kewajiban terhadap semua pihak yang terlibat dalam koperasi. Akibat hukum yang terjadi setelah dilakukannya pembubaran koperasi, yaitu badan hukum koperasi wajib dilakukan penyelesaian, transaksi operasional dihentikan, karyawan dapat diputuskan hubungan kerja, para anggota tidak dapat lagi mengundurkan diri, kekuasaan perangkat koperasi dibekukan juga digantikan oleh likuidator, dan pengurus maupun pengawas dapat diminta pertanggungjawabannya baik secara perdata maupun pidana jika terbukti karena kesalahan dan kelalaiannya koperasi mengalami kebangkrutan, Selain itu badan hukum dari koperasi tersebut juga akan dihapus. Jalan keluar yang bisa digunakan apabila koperasi dinyatakan pailit yaitu: Boleh dilakukan kompensasi piutang dan pengembalian simpanan anggota secara bertahap (Adnyani, 2015).

Berdasarkan masalah yang yang telah dibahas pada uraian uraian diatas, penulis berpendapat bahwa hak dan kewajiban merupakan bagian mutlak yang terdapat di dalam seseorang baik itu anggota, pengurus, pengawas dan juga koperasi itu sendiri yang memberi tanggungjawab kepada penerimanya. Dalam hal terjadinya pembubaran suatu koperasi maka koperasi mempunyai kewajiban untuk mengembalikan hak hak dari anggota dan juga nasabah yang terkena dampaknya yang bisa dilakukan dengan berbagai upaya seperti yang telah dijelaskan pada uraian diatas. Pembubaran koperasi juga badan hukumnya pasti memberi akibat hukum baik yang meliputi hak dan kewajiban kepada anggota pemegang sertifikat modal koperasi, pengurus, pengawas, karyawan dan para kreditor dan likuidator. Jika sebuah koperasi dibubarkan maka hak hak dari para kreditur koperasi akan berakibat hilangnya dana anggota tersebut. Apabila harta kekayaan koperasi tidak cukup untuk menutupi semua tuntutan (claim) yang diajukan oleh para kreditur. Koperasi bisa mempertanggung jawab perbuatannya baik secara sukarela atau dengan jalur hukum. Jika ditemukan unsur unsur kelalaian atau kesengajaan pihak tertentu maka yang bersangkutan wajib 
mempertanggung jawabkan perbuatannya baik secara perdata maupun pidana. Setelah semua urusan likuidasi hak kreditur dalam hal ini anggota koperasi selesai, selanjutnya dilakukan pengumuman pembubaran koperasi dalam berita Negara Republik Indonesia, sejak tanggal diumumkan pengumuman pembubaran status dari badan hukum koperasi sudah dihapus. Dalam kondisi sebuah koperasi mengalami pembubaran yang diikuti dengan proses penyelesaian maka tidak dimungkinkan untuk direhabilitasi menjadi badan hukum normal seperti sedia kala.

\section{SIMPULAN DAN SARAN}

\section{Simpulan}

Dari hasil dan pembahasan diatas maka ada beberapa kesimpulan yang dapat dibuat yaitu : Persyaratan pendirian dan pembubaran koperasi mengacu kepada Undang Undang Perkoperasian No 25 Tahun 1992. Pendirian koperasi juga diatur secara jelas baik bagi koperasi primer atau koperasi sekunder, Mekanisme pembubaran koperasi diatur dalam Undang Undang No 25 Tahun 1992 dan juga Peraturan Pemerintah Nomor 17 tahun 1994. Dan juga di dalam penelitian ini telah diuraikan faktor faktor yang menyebabkan koperasi pailit diantaranya, kredit macet, permodalan, perizinan usaha, dan manajemen sumber daya manusia yang belum optimal. Akibat hukum yang terjadi setelah dilakukannya pembubaran koperasi, yaitu badan hukum koperasi wajib dilakukan penyelesaian, transaksi operasionaldihentikan, karyawan dapat diputuskan hubungan kerja, para anggota tidak dapat lagi mengundurkan diri, kekuasaan perangkat koperasi dibekukan juga digantikan oleh likuidator, dan pengurus maupun pengawas dapat diminta pertanggungjawabannya baik secara perdata maupun pidana jika terbukti karena kesalahan dan kelalaiannya koperasi mengalami kebangkrutan, Selain itu badan hukum dari koperasi tersebut juga akan dihapus. Jalan keluar yang bisa digunakan apabila koperasi dinyatakan pailit yaitu: Boleh dilakukan kompensasi piutang dan pengembalian simpanan anggota secara bertahap. Di Dalam berkegiatan usaha koperasi, Undang-Undang memberikan sejumlah hak dan membebankan sejumlah kewajiban serta larangan kepada kedua pihak baik koperasi maupun anggota koperasi. Pengaturan tentang hak, kewajiban, dan larangan itu bertujuan untuk menciptakan hubungan bisnis yang sehat antara koperasi dan anggotanya, sekaligus menciptakan iklim berusaha koperasi yang kondusif bagi perkembangan usaha perekonomian nasional pada umumnya.

\section{Saran}

Sesuai dengan hasil penelitian ini, maka ada beberapa saran yang perlu disampaikan yaitu: Dalam hal pendirian koperasi penulis mengapresiasi langkah langkah yang telah dilakukan oleh pemerintah melalui Kementerian Koperasi dan UMKM yang telah melakukan reformasi dengan mengeluarkan UU Cipta Lapangan Kerja sehingga untuk mendirikan dan mengembangkan sebuah koperasi itu lebih dipermudah dalam hal birokrasi. Untuk pembubaran koperasi seharusnya tidak secara langsung menjadi dasar bagi pihak Kementerian Koperasi untuk melakukan pembubaran tetapi tetap melakukan usaha pembinaan dan penyelesaian agar sedapat mungkin koperasi dapat berjalan sehat kembali dan dana-dana para anggota tetap dapat dikelola kembali untuk kepentingan kesejahteraan anggota koperasi. Dan juga diperlukannya kajian terhadap Undang-undang Nomor 25 Tahun 1992 agar ada nuansa baru dalam perkoperasian di Indonesia.

\section{DAFTAR PUSTAKA}

Adnyani, N. K. S. (2015). Pengantar Ilmu Hukum dalam telaah Teori dan Praktik. Graha Ilmu, Yogyakarta.

Atmadja, I. D. G., \& Budiartha, I. N. P. (2018). Teori Teori Hukum. Setara Press, Malang.

Gultom, A. J., Hanifah, M., \& Fitriani, R. (2015). Pembubaran Koperasi yang Tidak Menjalankan Rapat Anggota Tahunan oleh Dinas Koperasi dan Usaha Mikro Kecil Menegah di Kota Pekanbaru. Jurnal Online Mahasiswa Fakultas Hukum, 5(1), 1-14.

Hendrawin, R. E. (2014). Manajemen Koperasi. CV Al Fath Zumar, Sukabumi.

Mahsar, K. A. (2020). Pelaksanaan Pembubaran Koperasi yang Tidak Aktif Berdasarkan Undangundang Nomor 25 Tahun 1992 Tentang Perkoperasian. Konferensi Ilmiah Mahasiswa UNISSULA (KIMU) 4, 518-530.

N.A, I. A., Prananingtyas, P., \& Mahmudah, S. (2016). Tanggung Jawab Pengurus Koperasi Terhadap 
Pembubaran Koperasi di Indonesia Ditinjau dari Undang-undang No. 25 Tahun 1992. Diponegoro Law Journal, 5(3), 1-10.

Riani, A. L. (2013). Manajemen Sumber Daya Manusia Masa Kini. Graha Ilmu, Yogyakarta. Rijanto, R. (2014). Aspek Hukum dalam ekonomi. CV Al Fath Zumar, Sukabumi.

Shubhan, M. H. (2009). Hukum Kepailitan, Prinsip, Norma, dan Praktek di Peradilan. Kencana Prenada, Jakarta.

Soemitro, R. H. (1998). Metode Penelitian Hukum dan Jurimetri. Ghalia Indonesia, Semarang. Tamba, H. (2008). Perspektif Sejarah Koperasi Indonesia. Aksara Persada Indonesia, Jakarta.

Udaya, J., Wennadi, L. Y., \& Anni, D. A. L. (2013). Manajemen Stratejik. Graha Imu, Yogyakarta. 